\title{
Artful Rhetoric: The Case of Lázaro de Tormes
}

\author{
Edward H. Friedman
}

\begin{abstract}
The anonymous Lazarillo de Tormes (1554), the first of the archetypal Spanish picaresque narratives, is a fictional autobiography in the form of a defense. A figure known as "Your Grace" has asked the adult Lázaro to explain "the case" (el caso), a public scandal. The narrator starts the presentation with his humble birth. The explanation is replete with satire and irony. Its complex rhetorical structure points to the lack of mobility in the hierarchical society of the time and place.
\end{abstract}

\section{Keywords}

Lazarillo de Tormes - picaresque - "the case" (el caso) - defense - irony - social satire

Despite its early date of publication (1554), its comparative brevity, and its precocious entry into the realm of narrative realism, the anonymous La vida de Lazarillo de Tormes y de sus fortunas y adversidades is an exceptionally - and perhaps deceptively - complex work. Lazarillo de Tormes is a sophisticated text on a number of levels. First and foremost, it offers an intricate rhetorical display, posing questions that require answers and answers that may be more open to interpretation than resolved unequivocally. There is a plan to the narrative, but the plan simultaneously presents arguments and counterarguments that intersect, or clash. The narrator is an adult who begins the story at his birth and deals with his childhood experiences, thereby inserting Lázaro and Lazarillo into the frame. Furthermore, a pronounced, if figurative, voice-over intrudes on the narration and on its particular rhetoric. Two dispositions seem to coalesce, one individual and the other comprehensive, one geared toward a narratee and the other geared toward readers, who bring their own literary and experiential baggage into the act of analysis. The breadth of the intertext of Lazarillo de Tormes complicates the proceedings in productive ways, as does the distinction between the genre of autobiography and the creation of pseudo-autobiography, which adds a new dimension to the structure. The arrangement of the material is highly significant. The operational scheme begins in the short but fundamental prologue, in which the narrative 
voice jointly addresses the author's circumstances and delineates the narrator/ protagonist's pretext. What may appear to be - and has been perceived as loosely connected, episodic, and random is carefully and skillfully fashioned to form a profound, ingenious, and unified narrative, an aesthetic object and a social document, with strong ties to the past, as inscribed into a pioneering and forward-looking design.

Lazarillo de Tormes is, among other things, a challenge to literary romance, namely, to the idealism of sentimental, pastoral, and chivalric narratives. Its satirical thrust evokes spiritual autobiographies and confessions, as well as the autobiographies of exemplary figures. As with Don Quijote some fifty years later, satire and parody are means to ends rather than ends in themselves; and, again as with Don Quijote, realism is complemented by metafiction, by self-referentiality and a self-consciousness of the writing process per se. Correspondingly, intertextuality is a key ingredient in the composition of Lazarillo de Tormes and Don Quijote. Imitation becomes far less a sincere form of flattery than a mechanism for rewriting, reshaping, and reinventing narrative technique. ${ }^{1}$ Lazarillo de Tormes recasts the hero as antihero, or picaro. Lofty achievements are transformed into tales from society's underside, but exhibiting the accoutrements of idealistic models. Romance is turned upside-down through an imaginative reordering, or recontextualization, of conventions. The stance of the narrator/protagonist, in the text and in society, distances him from his illustrious predecessors and removes him from the exalted space that they may occupy. Any deep structural bonds with romance are negated by the status, comportment, and reception of the picaro by his fellow citizens. Autobiography, by its nature, will provide at least two narratives, based on real events and on rewriting or selective memory. Some type of reformulation will affect what Hayden White classifies as the emplotment, or configuration, of a life story, given that truth is more often relative than absolute (esp. $83 \mathrm{ff}$.). A fictional autobiography expands the template to include a writer detached from the subject and situated in a mediating site. The narrator's contact with the narratee and the writer's contact with the reader lead to different story lines and, likely, to different, and possibly conflicting, conclusions. Story and discourse converge - enter into dialogue, as it were - as storytelling is clearly incorporated into the narrative layout. The dual, and frequently dueling, communications establish the rhetorical foundation of the richly encoded narrative and its dialectical sense of perspective.

1 For a discussion of the casuistry of literary imitation as it relates to the work that, building on Lazarillo de Tormes, solidified the notion of the picaresque genre, see David Álvarez Roblin's essay on Guzmán de Alfarache, in this volume. 
At this point it should be clear that Lazarillo de Tormes engages with the central concerns of casuistry: the virtuoso use of rhetoric to interrogate and explain confounding circumstances; the "problematizing" of exemplarity by representing a life story that is not an ideal model for imitation (to say the least), nor a clear expression of escarmiento, or negative moral precept; the cultivation of a subjectivity not only in "split psyche" of the protagonist-narrator, but also in the reader, who is more challenged by questions than instructed with answers; the experience of constructing meaning that is provisional and contingent rather than definitive (see the introduction to this volume). And, as we shall now consider in some detail, all of this is brought to bear on the elucidation of a particular "case."

The prologue to Lazarillo de Tormes is concise but hardly easy to decipher. The first-person account commences with an author who directs his words to a potential readership that he wants to please and entertain. He cites Pliny the Younger's dictum that there is no book so bad that it has no redeeming features. Even the most modest accomplishment can have some value. He then quotes Cicero, noting that writing can be a source of honor. Everyone desires praise, from the soldier to the priest. The holiest of those among us may be interested in saving souls, but they also are gratified when their parishioners laud their oratorical gifts. People revel in praise, whether it be merited or not. The author refers to his manuscript as a trifle (nonada), the story of a man no better than his neighbors, written in an unrefined manner, yet bearing the imprint of one who has endured misfortune, danger, and adversity. It is a story suitable of being told for that reason alone. Having justified his enterprise, the author cedes to the narrator/protagonist, who speaks to a narratee, Your Grace (Vuestra Merced), who has written to him to request a thorough explanation of "the case" (el caso). Contemplating the mandate, the narrator has chosen to start at the beginning, as opposed to in medias res, so that he will not have to omit relevant information. He makes the point that the triumphs of those who have assumed hardships from birth onward should not be measured according to the same criteria by which those on whom Fortune has smiled are judged. Success is a function of one's condition, milieu, and station in life. Those born of wealth and privilege must be considered separately. Those who have beaten the odds deserve credit for their fortitude, perseverance, stamina, and survival strategies; they are, quite literally, in a class by themselves.

The decidedly succinct prologue conveys a double focus and examples of doubling that will remain in effect throughout the narrative. The teller of the tale is, at once, an author cognizant of his readers and a mature narrator/ protagonist mindful of his obligation to Vuestra Merced, whose exact identity is unknown but who can be seen as an authority figure of some sort. While 
Lázaro de Tormes has been educated in the so-called school of hard knocks, the author is familiar with Pliny and Cicero. The prologue moves from the broad plane of fictional writing and reception to the immediate predicament of the central character. Not only is there vagueness with respect to Vuestra Merced, but the specifics of the "case" are likewise elusive. Nonetheless, a discursive maneuver is already in place. Lázaro will emphasize his humble origins in order to accentuate his determination and resilience, notwithstanding the obstacles that have faced him from his youth. The stimulus here is the demand for an elucidation of the case, and the response is a self-defense built around the transcendence of negative forces by a disadvantaged soul. Bloodlines and social rank will lie behind the defensive stratagem of a man in need of the sympathy of his arbiter. The prologue to Lazarillo de Tormes puts forth the dilemma of the protagonist and conspicuously signals a blueprint for the rationale that will follow. The precise parameters of the case and the identity of Vuestra Merced are mysteries. As will be seen in the prologue to Part 1 of Don Quijote, the fiction has now begun. This will not be a traditional autobiography in form or content. Lázaro de Tormes will juxtapose the requisite explanation of the case with a description of the hurdles over which he has prevailed - from birth to maturity - and he will mix the duty to comply with the inquiry and the goal of self-protection. Hence, the narrative will reflect a juggling act between the two objectives amid other series of binary oppositions: Lázaro and Lazarillo, the narratee and the reader, the past and the present, truth and poetic license, and, to be sure, narrative reliability and the abstract presence of what Wayne C. Booth terms, in The Rhetoric of Fiction, the implied author. ${ }^{2}$

In short, Lázaro's discourse is always mediated; never is a self-contained story recounted. The narration is multi-layered, with shifting weight, impact, implication, and consequence. The prologue may induce the reader to examine how the narrative is organized and how it transmits messages. The inner story will expose Lázaro's attempt to control the discourse and, certainly to some readers, it will reveal the matching and overriding intention of the author. Lázaro replies to Vuestra Merced in a calculated method of narration, aimed to distract from the issue at hand in favor of the chronicle of a social ascent, albeit moderate. Lázaro hopes to vindicate himself. The creator of his discourse may have contrasting ideas and contradictory motives. The construct of the implied author depends on the recognition of a competing discourse and a competing voice that is conjectural and hypothetical and yet overshadows and

2 For commentary on the implied author, see Friedman, The Antiheroine's Voice $16 \mathrm{ff}$. and Cervantes in the Middle $40 \mathrm{ff}$. 
supersedes the concrete sign systems of the narrator. Lázaro's narrative is both wide-ranging and concentrated. The boy who seems to be doomed to failure suffers numerous calamities and tribulations, but he carries on, refusing to give up, refusing to be defeated. In the end, he has made something of himself. He categorizes his vocation as respectable. His explanation of the case rests on an apparent evasion of the damaging aspects of the state of affairs and a highlighting of advancement in society. Lázaro's autobiographical impulse allows him to divert attention from facts that could be detrimental to a self-serving posture, as the narrator converts a personal quandary into a success story. The link between story and discourse is rhetoric. Lázaro initiates his remarks by observing that society's dispossessed warrant extra consideration for their attainments, no matter how meager they may be, under oppressive protocols and the constant scrutiny of their superiors. Rhetoric is, after all, the art of persuasion, and Lázaro endeavors to convince Vuestra Merced of his worth as a citizen. The proposal is logical, if a bit convoluted. Its execution is rendered more elaborate by the intervention of a rival voice.

Lázaro writes his defense with a plan in mind. He conceives a cautious and deliberate path to apprise Vuestra Merced of his rites of passage and his role in society. Structure and content are conspicuously interdependent. Lázaro's mode of presentation touches a range of intertextual elements, literary and nonliterary. The degree of irony that encompasses this exercise is astonishing, and more so when the intercession of the implied author attaches to the narrative scenario. Irony is the guiding trope of the text and a major facet of its dialogical intensity. Irony is the mark - and the marker - of the implied author. Lazarillo de Tormes takes point of view to extremes, and that is one of its strengths. The progression of the plot depicts the stages of the protagonist's development, but it may be the interplay of perspectives that most patently animates the narrative and engages the reader. Vuestra Merced obviously knows much about Lázaro de Tormes. The author seems to expect readers to have a command of the intertext, since satire and parody cannot exist in a vacuum. In the middle position, the implied author forges a semiotics of perception. That is, the author has to trust the reader to discern, acknowledge, and comprehend the signs, the clues to the multi-tiered structure of the narrative. The author invites the consumer of literature to read between the lines. The embedded signs within the narrative can be seen as the input of the author, whose presence in the text is implicit. In the prologue to Part 1 of Don Quijote, Cervantes casts a fictionalized version of himself as narrator, and this persona, who could be designated as "Cervantes," converses with a "friend," the alter ego of an alter ego. The discussion of the precepts for the writing of prologues occupies much of the prologue, or, in essence, the metaprologue. The friend 
advises "Cervantes" to ignore the customary rules for composing a prologue with quotations from venerated sources - by filling in the allotted space with anything that strikes his fancy. The prologue inaugurates the fictional venture, with allusions to the targeted destruction of the romances of chivalry, but with an air of subversion, a confrontation with authority in and beyond literary norms. Cervantes is the historical author, outside the text. "Cervantes" and the friend are characters inside the text. The instigator of theoretical subversion and the purveyor of alternative and ironic signs is the implied author, whose presence is insubstantial, felt rather than embodied. Lazarillo de Tormes anticipates this set of narrative relations.

In reading the text, one must bear in mind the questions of the identity of Vuestra Merced and the subject of the "case" while speculating on the cohesiveness of Lázaro's argument and defensive strategies, as introduced in the prologue. The reader may analyze the narrator's structuring of his story: the division into chapters (tratados, literally treatises), the primary content of each chapter, the frames, the varying lengths of the chapters, the motif of hunger, the search for a proper identity, the transitions, and the turning points. There are crucial dialectics at play: the indicators of Lázaro's objectives and statements that would seem to interfere with these objectives, reversals of what would seem to be Lázaro's intentions, crossings of a defense with a success story, propositions that appear to support Lázaro's reasoning and those that refute his contentions, and so forth. The reader can assess, sequentially, the steps of the narrator's self-defense and the segments of his argumentation, together with evidence of an ironic counter-discourse in the exposition. On occasion, Lázaro may go off-topic, and these digressions can hint at ulterior motives. His compliance with Vuestra Merced's request for an explanation of the case takes an intertextual route, influenced by autobiography, confessional literature, popular culture, the Bible, romance, idealism in general, and the Italian novella and incipient realism. Lazarillo de Tormes is distinguished by an overwriting or rewriting of the story by the implied author, an abstraction with a contrary agenda and an ironic bent. In the expansive and fluctuating center of the text stand literature, society, and the status of the individual, ripe for evaluation and reevaluation. ${ }^{3}$

3 The intertext of Lazarillo de Tormes naturally includes the extensive critical bibliography on the text. I would like to note six essays that have informed my comments here. I have learned from these scholars (and many others), and I have bounced my ideas off of theirs: Frank Casa, Alfonso J. García Osuna, David Gitlitz, Rosa Navarro Durán, George A. Shipley, and Carolyn Wolfenzon. I am indebted to them and to their professional colleagues who have guided me over the years. I have included among the Works Cited a selection of my previous essays on Lazarillo de Tormes. 
In Lazarillo de Tormes, the deep structure of idealism aids the cause of realism. Tratado 1 opens with the protagonist's genealogy, the antithesis of a noble pedigree or the celebrated lineage of a knight errant. Lázaro's father was in charge of a mill on the river Tormes, where his wife visited just before she went into labor. Lazarillo de Tormes may resemble Amadís de Gaula or Belianís de Grecia as an appellation but not as a gauge of notability. When Lazarillo is eight years old, his father is accused of theft and imprisoned. The former miller is permitted to enlist in an expedition against the Muslim enemy as muleteer for a gentleman soldier, and he loses his life in combat. He can be praised for his service to the faith, but he is a criminal who leaves his widow in dire straits. Lázaro's impoverished mother strives to better her lot by, as the proverb says, aligning herself with the good people in order to become one of them ("arrimarse a los buenos por ser uno dellos" [10]). ${ }^{4}$ She moves to Salamanca, where she finds work as a cook and washerwoman for stableboys. She becomes attached to Zaide, a dark-skinned man, who brings her food and often spends the night. Lazarillo soon has a baby brother, who is frightened of the looks of his father, calling him a bogeyman. Lázaro comments in an aside that, in spite of his tender age, he was able to grasp that people do not see in themselves what they run away from in others. Like the deceased father, Zaide is a thief, and he makes Lazarillo's mother his accomplice. The officers of justice are suspicious, and they corner and threaten Lazarillo, who out of fear for his own welfare blurts out what he knows. Zaide is apprehended, and he and Lazarillo's mother are severely punished for their offenses. The beleaguered woman tries to make amends. Attentive to her two sons, she toils as a servant at an inn, where Lazarillo runs errands for the clientele. Beset by poverty and a bad reputation, she elects to confer the guardianship of Lazarillo to a blind man who is staying at the inn, advising him that the boy is the son of a good man who died while waging war against the foes of Christianity. The blind man agrees to receive Lazarillo as a son; he maintains that each in his own way will guide the other.

Lázaro portrays his time with the blind man as a period of profound learning, a period of disillusionment (desengaño) in which he loses his innocence. It is he who is blind to reality and his master who sees through the boy's tricks involving a linen sack, a wine bottle, a bunch of grapes, and a sausage. The episode of the blind man institutes the motif of hunger whereby Lazarillo must fight for his very survival. The blind man has vowed to instruct his charge as a father might instruct a son, but he comes close to starving the boy as he mocks and ridicules him before any onlookers who happen to be nearby. Lazarillo

4 All quotations from Lazarillo de Tormes will refer to the Rico edition. 
absorbs from his master the art of winning people over with charm, wellpracticed sincerity, and ruses to earn compassion. Among the insights is an understanding of sight itself. Lazarillo escapes from the blind man by reversing the roles; his master has taught him not to be blind to his surroundings, and the boy uses his visual aptitude to devise an opportunity for flight. In this rendition of the story, the victim outsmarts the victimizer, who has trained him to do so. The ironic twist coordinates with other ironies. The observation of his little brother's reaction to his father will later relate to Lázaro himself, and so will his inability to keep silent about Zaide when intimidated by the law enforcement agents. Blindness and silence, real and figurative, help to determine Lázaro's fate at the beginning and the end of his narrative. The written testimony will unmask - and undermine - his tactics and his fabrications. The first chapter of the defense has Lázaro describing his heritage, the background and destinies of his parents and stepfather, and his ordeal with the first of his masters. The inversion of romance formulas and the angle of vision from the depths of society deflate the paradigms of idealistic fiction. Lázaro stresses his lowly origins to let Vuestra Merced appreciate his lack of options, his vulnerability, and his deprivations. Lázaro's rhetorical strategy interacts with the power of satire and with an ironic structure that will continue and will grow exponentially as the narrative proceeds. The narrator's words, in sum, may not be self-protective, nor will his control of the discourse be conclusive or freestanding. By the same token, a portion of the ironic machinations targets society at large, to be dissected at the time of composition and thereafter.

Having left the blind man, Lazarillo finds employment with a miserly priest who intensifies the concentration on hunger. The precariousness of the boy's existence has gone from bad to worse, for his new master is sighted, vigilant, and exaggeratedly parsimonious. To his shame, Lazarillo is reduced to praying that parishioners meet their maker so as to satisfy his appetite at their funerals and wakes. Aided by a tinker who makes him a key, he steals morsels of bread from the priest's locked chest, which becomes his "breadly paradise" ("paraíso panal" [33]). He attributes the thefts to a mouse and finally to a snake. The priest is beside himself. Protecting the key by keeping it in his mouth as he sleeps, Lazarillo inadvertently emits a sound that rouses his master, who discovers the hoax, bashes his servant in the head, and dismisses him. Breaking a silence has again had a painful outcome. From the perspective of Lázaro, the second tratado demonstrates how he leaps from the frying pan into the fire. Hunger moves him to near-starvation. His ingenuity is put more relentlessly to the test by a callous, unfeeling, and watchful master dedicated to safeguarding the chest at all costs. This is a master who encroaches on what little 
privacy that Lazarillo retains and who incessantly can hover over him. Lázaro foresees a question from Vuestra Merced as to why he did not run away from this wretched situation; and he responds that he was afraid that, in light of his record to date, he might fare even more poorly with a third master. For the anxious boy, the next rung on this unsteady ladder could be death. He stays with the priest until he is ejected in disgrace. His hunger will persist.

Tratado 2 traces Lazarillo's mounting isolation and sense of solitude. The chapter concerns the picaro's encounter with a representative of the Church, who proclaims his magnanimity as he feeds the boy mere crumbs and gravy with no meat. That the priest is adept at hypocrisy - in word and action scarcely seems coincidental, and he is but one of an array of ecclesiastical figures in the text. The episode is filled with images associated with rituals and the daily routine of the cleric, from charitable donations to the collection box, from officiating at services to ministering to the infirm and needy, with food and remuneration as common themes. In this instance, faith is compromised, debased. The ramifications are more damaging and more derogatory than Lazarillo's desperate efforts to stay alive. Interestingly, Lázaro's discourse in this chapter is replete with religious vocabulary and references to prayer, confession, God's pardoning gestures, miracles, Saint James, saying grace and saving grace, the devil, and more. Lázaro prolongs his enumeration of ills, and the narrative - be it wittingly or unwittingly - illuminates the complicity of society, and of its most sacred institutions, in the behavior and transgressions of its outcasts.

After his banishment from the priest's quarters, Lazarillo, in distress, makes his way to Toledo, where he accepts handouts while his wounds heal. Those he meets warn him that he must look out for himself. He chances upon a man who is well dressed and looks prosperous. Fortuitously, or so it would seem, the gentleman asks if the boy is looking for a job. When Lazarillo answers in the affirmative, the man declares that this must be his lucky day. The boy informs his new master of his personal history, underscoring only the good points; that is, he lies - a habit, Lázaro admits to the narratee, at which he is proficient. Lazarillo's initial exhilaration is quickly crushed, as disillusion once more rears its ugly face. The gentleman is a squire, but he currently is disenfranchised from the benefits of class, and his aura of affluence is a façade. His outward appearance is imposing, but there is nothing on the inside. His home is dark and bleak, with, at most, a paltry supply of food. The liquid refreshment is water, not wine. Lazarillo shares his leftover bread with the penniless squire, and he will later hunt for - and beg for - provisions for the two of them. The chapter illustrates Lazarillo's plight. He must prevent himself and his master 
from dying of starvation, at a time in which statutes against beggars escalate. The squire is not malevolent or merciless, but excessively proud. He is devoted to and trapped by the code of honor, which precludes manual labor for a person of his rank. He risks public humiliation for his penury because his top priority is his reputation, his honorability. Adherence to the prescribed regulations is immutable and nonnegotiable. Lázaro relates the squire's exhaustive story of his unswerving allegiance to the code of honor and the repercussions of this obsession, which the boy ascribes to vanity. Although he is kind to Lazarillo, the squire jeopardizes the safety of his servant. A benevolent employer does not alter the operative motif of hunger rekindled and exacerbated from one master to his successor. When creditors pursue the squire, he runs away, leaving Lazarillo destitute and on his own. The young boy is exonerated when neighbors testify on his behalf to the constable who has come to investigate. Lazarillo's wellbeing is bound to his master's commitment to the concept of honor, and Lázaro interpolates a social critique predicated on the fusion, or confusion, of reality and appearances. It is of considerable importance that he disapproves of the squire's compulsive attachment to a rigid code of conduct. The young boy and the mature adult pass judgment on the squire. Matters of honor will reenter the narrative at future junctures.

Lazarillo's fourth master is a Mercedarian friar for whom the monastery holds negligible appeal. The friar cannot stay put; he prefers to traipse around, and the boy must accompany him on his ramblings, entailing visits of a more secular than spiritual orientation. As narrator of tratado 4, the briefest of the chapters, Lázaro seems to want to disclose few particulars, yet the breaking of silence is again notable. He does mention that the friar gave him the first pair of shoes that he wore out, in only a week. The rapid pace is too much for Lazarillo, who takes his leave, noting famously, "for that reason and for other little things that I will not speak of" "por eso y por otras cosillas que no digo" [67]). The language is suggestive. The pronouncement of the elimination of details could lead one to think the worst, about the friar and possibly about the impressionable boy. The chapter is a segment of the narrative, left open, but intended, within one plan or another - or within more than one plan - to be interpreted, to fill in gaps.

Tratado 5 tells of Lazarillo's service to a pardoner, a seller of papal indulgences who manages the responsibility honestly if he can and dishonestly if he cannot. Vital to this chapter is Lazarillo's role as a witness to the activities of the pardoner. The report is narrated from the boy's point of view as he comes to understand the artifice and the modus operandi of his master. When sales are at a standstill, the pardoner enlists the assistance of accomplices and 
contrives "miracles" so as to sustain an atmosphere of wonderment and to inspire purchases. When the pardoner realizes that Lazarillo is aware of his scams, he admonishes the boy to stay mum. Lazarillo decides that this would be to his advantage, and he remains silent (until now). Lázaro comments that even as a lad he was able to see the ease by which swindlers can manipulate the innocent and the naïve; he himself was not wise to the fraudulent ploys. There seems to be a touch of admiration in this reflection. Lazarillo is, for the most part, absent from the plot of this chapter. He is a spectator of the metatheater of the pardoner, another of the instructors in this rudimentary program of education. Lazarillo's figural disappearance in the fifth chapter heralds a transition. Life is not uncomplicated, but hunger is no longer a problem. The boy is growing up. Raymond Willis, in "Lazarillo and the Pardoner," proposes that the fifth tratado lets the author take the protagonist from boyhood through adolescence to young adulthood in the sixth tratado, which segues into the seventh and final tratado, wherein Lázaro has a legitimate profession and a wife.

In the sixth chapter, Lázaro writes of his job mixing colors for a painter of tambourines. He describes the job as harsh - "sufrí mil males" ("I suffered a thousand ills" [75]) - without further elaboration. He labels himself a mozuelo, a young man on the move. Opportunity knocks. A chaplain gives Lázaro a more agreeable position as a water seller and furnishes him with a donkey, four jugs, and a whip to perform his chores. He pays the chaplain a commission and earns an adequate income. After four years in the trade, Lázaro can afford to purchase, by his standards, upscale clothing, the articles of which he takes care to itemize: a well-worn fustian jacket, a coat that has seen better days, and a cloak that is lacking its original fringe border, along with an old-fashioned sword. Dressed to the nines in his second-hand garments, Lázaro feels that the job of selling water is beneath him. He returns the donkey to the chaplain and, with an upward glance, he embarks on a new path. In tratado 6, Lázaro may overstate the elegance of his new wardrobe, but he is documenting another phase of his rise in society. He is nearly self-sufficient, and he backs away from menial labor. He wants to move forward, and when he looks in the mirror at his well-clad image, he envisions a better life, one of prosperity and inclusion. It would be difficult not to notice that Lázaro's recent acquisitions parallel those of this third master, the square: un jubón, un sayo, una capa, una espada. Lázaro has condemned the squire's inordinate pride and obsession with honor, yet, consciously or unconsciously, he emulates his former master, with striking emblems that connect the two. To an extent, the seventh tratado is constructed around the theme of honor. Lázaro's response to Vuestra Merced - his explanation of the case - is attendant on the stand of each apropos of what constitutes 
the honor of an individual and which individuals are entitled to be integrated into the framework of honor.

The time spent under the supervision of the chaplain is by far the longest period with a master. When he departs, Lázaro is an adult, confident and primed to participate in mainstream society. He finds work with a constable, a symbol of law and order, but the perils outweigh the prestige. When a group of fugitives attack and wound the constable, Lázaro reneges on his agreement and looks for a safer occupation. In search of an appropriate long-term position and eager to improve his lot (medrar), he succeeds in obtaining "un oficio real" (77), a civil service appointment that, stretching the point, could be regarded as a bare-bones "royal office." He is a town-crier, tasked with announcing wines for sale, merchandise on the market, auctions, and lost articles, and he must join the convoy of prisoners charged with crimes so that he can shout out their alleged misdeeds. Very little happens in Toledo that does not reach the eyes and ears of Lázaro de Tormes, who boasts that he has his hands - or, more accurately, his mouth - in almost all affairs in the city. Overwhelmed by his good fortune, Lázaro expresses gratitude to the friends and sponsors who have encouraged and guided him. Above all, he thanks God for answering his prayers and Vuestra Merced for being his advocate. He notes that at the time of writing he still has the position and is still deeply beholden to God and Vuestra Merced. He seems to be getting closer and closer to explaining "the case."

Lázaro receives the patronage of the Archpriest of San Salvador, who is grateful for the enthusiasm and resourcefulness that the town-crier puts into publicizing his wines. Lázaro refers to the archpriest as "my master" and says he is "at the service of and friend to Vuestra Merced." The archpriest is so fond of Lázaro that he offers to set up a marriage between his employee and one of his maids. Lázaro sees no wisdom in rejecting the gracious proposal, which could only strengthen the relationship with his mentor. The marriage is celebrated, and Lázaro sings the praises of his wife, who is diligent and accommodating, and of the archpriest, who attends to the couple and bestows food, cast-off clothing, and other gifts on them. The archpriest invites them to dine with him on Sundays and holidays, and he locates a home near his own for them to rent. This harmonious lifestyle is disrupted by malicious gossip from neighbors who assert that Lázaro's wife goes to the archpriest's residence to cook his meals and make his bed, spending extra hours that leave her open to suspicion. Lázaro admits that this is true, but he wants to curb the rumors in order to preserve the sanctity of his marriage and the backing of the archpriest. His wife does not take the public airing of her labors lightly. Lázaro recalls the words of the archpriest, uttered in the presence of his wife, to the effect that 
nothing untoward goes on when she is working in his home, and that Lázaro should pay no mind to the wagging tongues, but instead to his best interests. Lázaro wholeheartedly endorses the recommendation, indicating that he has pledged unwaveringly to align himself with the good people. He concedes, nevertheless, and before the woman in question, that friends have verified to him that his wife had given birth three times prior to their wedding. The woman becomes enraged; she cries, and then vigorously screams and curses at the man who arranged the marriage. Lázaro instantly regrets his words, and he is so upset that he says he wanted to die on the spot. With some pain on all sides, the two men calm the despondent woman, assuring her that from now on her faithfulness will not be interrogated. Lázaro promises never to broach the topic of how she fulfils her duties; his wife's right to enter the archpriest's quarters and to stay for as long as she pleases will be inviolable. Each of the three is satisfied with the outcome.

Lázaro punctuates his outlook by quoting himself in response to those that he senses are about to disparage his wife. He denounces those who would put her and the marriage in harm's way. He cautions his friends against gossipmongering, against spreading any tales that would cause friction between him and his spouse, whom he values more than anything else in the world. God has granted him domestic bliss, more than he deserves. He is willing to swear "on the consecrated host that she is as good as any woman living within the gates of Toledo" ("sobre la hostia consagrada que es tan buena mujer como vive dentro de las puertas de Toledo" [8o]) - an intense statement open to double meaning - and he is prepared to kill anyone who says otherwise. His neighbors take the warning seriously, and there is peace in his home. Lázaro concludes by recording that this culminating incident has occurred at the moment in which the glorious emperor Carlos I has entered Toledo to hold parliament, and he adds that "at this time I was living in prosperity and at the height of all good fortune" ("en este tiempo estaba en mi prosperidad y en la cumbre de toda buena fortuna" [80]). Conflict seems to have been resolved and order restored. In Lázaro's estimation, the archpriest has no qualms. Lázaro's wife can come and go as she wishes. Lázaro's fellow citizens have respected his plea for silence. The case is closed. Or is it?

At the end, the enigmatic elements of the prologue remain in force. Vuestra Merced is an authority figure. The seventh tratado alludes to his association with the archpriest, but the gentleman's specific identity is not clarified. The "case" that requires an explanation probably is a supposed scandal emanating from the service of Lázaro's wife to the archpriest. Lázaro insists that the dispute has been settled, but nothing else in the narrative would seem to qualify 
as the "case." The explanation exonerates the three parties - husband, wife, and employer - and stresses closure. Social, professional, and personal prosperity leads to the happy ending. Lázaro's rhetorical strategy, initiated in the prologue, is corroborated in the narrative proper. The explanation is a success story, a victory over unceasing hurdles and barriers, from a vulnerable child facing starvation to a man seeking a decent place in a society poised to shun him. The trials of his youth lead Lázaro to a position of trust and the support of - and dependence on - eminent benefactors. There is a pervasive sense that something is missing. There may also be a feeling that Lázaro is not in full control of the discourse. The picaro's commentary is not consistently favorable to his self-defense, and his struggle for upward mobility cannot avoid the proscriptions of social policies. Lázaro's narration vies with a formidable counter-discourse grounded in irony. The imagery and the circumstances have circular patterns. The widowed mother goes to Salamanca to band with - arrimarse $a$ - the good people, and her troubles multiply. Lázaro repeats the adage when he speaks of his move to Toledo. The most extended motifs relate to the dichotomies silence/speech and blindness/sight. From his childhood days, as in the revelation of Zaide's thefts and the "otras cosillas que no digo" about the escapades of the friar, to the admonition to his friends in Toledo, among other examples, Lázaro breaks protective silence and in so doing incriminates others - and himself. Similarly, the play with vision and blindness with the first master continues to the end, when Lázaro chooses to close his eyes to the goings-on at the archpriest's residence. He pushes an agenda of composure and serenity by trying to expunge, if not always credibly, any tinge of discord.

When the narrator/protagonist's words work against him - against his explanation of the case - the implied author would seem to intervene and to heighten the irony. The parody of literary idealism and the ensuing distortion of the intertext are interposed with social realities as Lázaro becomes increasingly distanced from the center of message production. His comments and judgments reverberate against him as the narrative progresses. Lázaro (and Lazarillo) will pause to criticize the squire's obsession with the honor code, but the "case" - the motivating factor of the narrative - may hinge on the husband's preoccupation with appearances and respectability. Lázaro can relish the creature comforts that eluded him as a boy, but the very practices that he has derided in the past shape his thoughts and actions. The purchase of apparel in the sixth tratado is a harbinger of the change of attitude. Lázaro dissociates himself from a fixation with the tenets of the honor code and then contradicts himself by clinging to its principles, so that the world can see him as worthy of the social standing that he professes to enjoy. The stance is ironic, for if Lázaro genuinely has subscribed to the honor code, his tranquility will be 
unremittingly under siege. For true believers, this would be worse than starvation, worse than death. If he is not truthful, he forfeits the clout that he claims to have; he will forever be an underling, and his success story rings false. In the closing paragraph, Lázaro links his narrative to the arrival of the emperor in Toledo. He may be striving for similitude, but the result is radical difference. The text reexamines the scope and the stumbling blocks of institutionalized honor. There may be threads of subversion, as there may be, as well, in the representation of religious characters whose hypocrisy surpasses their piety. In the process, the anonymous author redefines the perimeters of satire and the design of narrative, as Cervantes would do, sui generis, in Don Quijote.

Lazarillo de Tormes is about literature and about society. The author takes the appurtenances of idealistic fiction and exemplary autobiography and turns them inside out. The narrative starts at the bottom, not at the top, and the inversion is meaningful. Unlike the protagonists of romance, Lázaro is a product of literary and social determinism - a product of environment and heredity and he submits an account of his growth and development, physical and psychological. The satirical edge places the narrator/protagonist in an awkward, and untenable, position: his explanation of the case becomes self-parody. His own words do him in, and one may suspect that they are not his own words. Lázaro's objective is to demonstrate the overcoming of his unprepossessing origins and his subsequent rise in society, yet he is continually outvoiced by the abstract creator of an ironic subtext. Lázaro substitutes making his own case for explaining "the case," but the implied author conspires against him. Lázaro wants to elevate himself in the eyes of Vuestra Merced, but his plan may backfire as the narrative confirms his status as a perennial outsider. The inalterable position excludes the kind of honorability to which Lázaro aspires, and he moves from subject to object. Conversely, and ironically, the satirical trajectory gives him a principal, or the principal, role in the narrative, the equivalent of which society roundly denies him. The fictional project rescues - or, one might say, resurrects - Lázaro and those of his ilk from oblivion. Additionally, the vision of society is less than heroic, less than admirable. Among the paradoxes of irony is the mutability of reception. Views of the antihero and of the dynamics of the individual versus society are not bound by the reigning temperament of mid-sixteenth-century Spain. Ultimately, the text is open rather than closed, ambiguous rather than unambiguous, exhibiting a paradoxical consistency. It appeals to distinct, and varying, sensibilities. Whatever one's readerly inclinations, a persona can be identified behind the mask of fiction.

Lazarillo de Tormes can be deemed a case study. As if in a courtroom situation, Lázaro states his case, which takes the form of an explanation of "the case," offered to the petitioner, known only as Vuestra Merced. The 
prologue - addressed jointly to an imagined readership and to the narratee alludes, respectively, to entertainment and instruction and to compliance with the request. The macrocosm would seem to be the book and the microcosm the fictional account; that is, the text subsumes the pretext. The author and the implied author exert the highest degree of control, while the narrator/protagonist impeaches himself on a regular basis. There is a discernible correlation between Lázaro's role in the discourse and his role in society; the character does not govern his fate. This analogue becomes the foundation of the narrative. The brilliant and complex literary experiment is, at the same time, a social document, and each is contingent on the whims of fortune, circumstance, context, interpretation, and revisionism. The connection to jurisprudence is unmistakable, as is the connection to moral conscience. The satire never lacks seriousness of purpose. The mockery and deprecation of the lower classes may have been a source of humor, but mean-spiritedness can defeat itself in the long run; authoritarian ideologies tend to have limited lifespans. Sociologists of literature and contemporary readers are able to rethink and amplify the field of study, confronting precedents and proffering new hypotheses. Analysis is flexible, conditional, transitory. Lazarillo de Tormes is a uniquely evocative text. Its intricacies belie its date of publication. The narrative satirizes idealism as it validates realism through a novel and novelistic approach. The assessment of ethical points and, therein, issues of right and wrong are supremely indeterminate, prompting dialogue from many vantage points. Irony is the leading trope of Lazarillo de Tormes, and irony unfailingly yields to irony. The final irony - or, more accurately, the penultimate irony - of the narrative is that the predominant voice is that of Lázaro de Tormes, whose strains rise above the competing voices in a decentered center. He may lose "the case," but he wins the fight for survival and innovation.

\section{Works Cited}

Booth, Wayne C. The Rhetoric of Fiction. Chicago: University of Chicago Press, 1961. Casa, Frank P. "In Defense of Lázaro de Tormes." Crítica Hispánica 19.1-2 (1997): 87-98. Cervantes, Miguel de. Don Quijote de la Mancha. Ed. Francisco Rico. 2 vols. Barcelona: Crítica, 1998.

Cervantes, Miguel de. Don Quixote. Transl. Edith Grossman. New York: Ecco, 2003.

Friedman, Edward H. The Antiheroine's Voice: Narrative Discourse and Transformations of the Picaresque. Columbia: University of Missouri Press, 1987.

Friedman, Edward H. Cervantes in the Middle: Realism and Reality in the Spanish Novel from Lazarillo de Tormes to Niebla. Newark, DE: Juan de la Cuesta, 2006. 
Friedman, Edward H. "Chaos Restored: Authorial Control and Ambiguity in Lazarillo de Tormes." Crítica Hispánica 3 (1981): 59-73.

Friedman, Edward H. "Coming to Terms with Lázaro's Prosperity: Framing Success in Lazarillo de Tormes." Crítica Hispánica 19.1-2 (1997): 41-56.

Friedman, Edward H. “'Cómo se hace un autor': Lazarillo de Tormes and the Rigors of Anonymity." Studies in Honor of Donald W. Bleznick. Eds. Delia V. Galván et al. Newark, DE: Juan de la Cuesta, 1995: 33-48.

Friedman, Edward H. "The Fortunes of Irony: A Metacritical Reading of Lazarillo de Tormes." Essays in Literature 15.2 (1988): 285-93.

Friedman, Edward H. "From the Inside Out: The Poetics of Lazarillo de Tormes." Philological Quarterly 89.1 (2010): 13-30.

Friedman, Edward H. “'El pobre servicio de mano': Lazarillo de Tormes, Don Quixote, and the Design of the Novel." 1605-2005: Don Quixote across the Centuries. Ed. John P. Gabriele. Madrid and Frankfurt am Main: Iberoamericana/Vervuert, 2005: 29-50.

Friedman, Edward H. "Roads Untaken: The Spanish Picaresque Novel." A History of the Spanish Novel. Ed. J.A. Garrido Ardila. Oxford: Oxford University Press, 2015: 96-121.

García Osuna, Alfonso J. “Eros y Ágape en la voz de Lázaro de Tormes.” Hispanic Journal 33.1 (2012): 11-22.

Gitlitz, David. "Inquisition Confessions and Lazarillo de Tormes." Hispanic Review 68.1 (2000): 53-74.

Lazarillo de Tormes. In Novela picaresca española, I. Ed. Francisco Rico. Barcelona: Planeta, 1967: 1-8o.

Lazarillo de Tormes. In Two Spanish Picaresque Novels. Ed. and transl. Michael Alpert. Harmondsworth, Middlesex, England: Penguin Books, 1967: 21-79.

Navarro Durán, Rosa. "Dar la palabra al texto de La vida de Lazarillo de Tormes." Revista Canadiense de Estudios Hispánicos 41.1 (2016): 11-33.

Shipley, George A. "The Critic as Witness for the Prosecution: Making the Case against Lázaro de Tormes." PMLA 97.2 (1982): 179-94.

White, Hayden. "The Historical Text as Literary Artifact." Tropics of Discourse: Essays in Cultural Criticism. Baltimore: The Johns Hopkins University Press, 1978: 81-10o.

Willis, Raymond S. "Lazarillo and the Pardoner: The Artistic Necessity of the Fifth Tractado." Hispanic Review 27.3 (1959): 267-79.

Wolfenzon, Carolyn. "Unidad y fragmentacion en Lazarillo de Tormes." Hispanófila 149 (2007):1-16. 